\title{
Late Quaternary changes of western equatorial Atlantic surface circulation and Amazon lowland climate recorded in Ceará Rise deep-sea sediments
}

\author{
Carsten Rühlemann, ${ }^{1}$ Bernhard Diekmann, ${ }^{2}$ Stefan Mulitza, ${ }^{1}$ and Martin Frank ${ }^{3}$
}

\begin{abstract}
Today the western tropical Atlantic is the most important passage for cross-equatorial transfer of heat in the form of warm surface water flowing from the South into the North Atlantic. Circulation changes north of South America may thus have influenced the global thermohaline circulation system and high northern latitude climate. Here we reconstruct late Quaternary variations of western equatorial Atlantic surface circulation and Amazon lowland climate obtained from a multiproxy sediment record from Ceará Rise. Variations in the illite/smectite ratio suggest drier climatic conditions in the Amazon Basin during glacials relative to interglacials. The ${ }^{230} \mathrm{Th}_{\mathrm{ex}}{ }^{-}$ normalized fluxes and the ${ }^{13} \mathrm{C}^{12} \mathrm{C}$ record of organic carbon indicate that sea level fluctuations, shelf topography, and changes of the surface circulation pattern controlled variations and amplitude of terrigenous sediment supply to the Ceará Rise. We attribute variations in thermocline depth, reconstructed from vertical planktic foraminiferal oxygen isotope gradients and abundances of the phytoplankton species Florisphaera profunda, to changes in southeast trade wind intensity. Strong trade winds during ice volume maxima are associated with a deep western tropical Atlantic thermocline, strengthening of the North Brazil Current retroflection, and more vigorous eastward flow of surface waters.
\end{abstract}

\section{Introduction}

At present, the western tropical Atlantic is the main passage for the transfer of warm surface water from the South into the North Atlantic. From about February to May, the North Brazil Current (NBC) continuously flows northwestward along the north Brazilian coast into the Gulf of Mexico (Figure 1), and heat transport from the tropics to higher northern latitudes is at maximum [Philander and Pacanowski, 1986]. Between June and January, when the NBC turns eastward to merge with the North Equatorial Counter Current (NECC), northward heat transport significantly weakens. Long-term changes in the annual duration of this retroflection, as was suggested for millennial-scale events during marine oxygen isotope stage (MIS) 3 [Maslin et al., 1997], may also have modified heat export from the South Atlantic on glacialinterglacial timescales, possibly contributing to the development of the global ice age climate cycles. Because of its potential influence on high northern latitude climate it is important to reconstruct the history of past changes in western tropical Atlantic surface circulation. The Ceará Rise, an aseismic morphological high that ranges between 3 and $4.5 \mathrm{~km}$ water depth and is located northeastward of the Amazon delta,

\footnotetext{
'Department of Geosciences, University of Bremen, Bremen, Germany.

${ }^{2}$ Alfred Wegener Institute for Polar and Marıne Research, Bremerhaven, Germany

'Institute for Isotope Geology and Mineral Resources, Department of Earth Sciences, ETH Zentrum, Zurich, Switzerland
}

Copyright 2001 by the American Geophysical Union.

Рaper number 1999PA000474.

0883-8305/01/1999PA000474\$12.00 is an ideal location for such a study because terrigenous matter supply from the Amazon River mouth to the top of the rise is mainly by transport within the upper water column [Francois and Bacon, 1991]. Today, this transport seems to occur within the seasonal retroflection of the NBC eastward into the NECC [Müller-Karger et al., 1988]. Thus unraveling the terrigenous sediment record of the Ceara Rise provides valuable information regarding the late Quaternary history of the western equatorial Atlantic surface current system. Here we reconstruct changes in sea surface hydrography and Amazonian climate during the past $380 \mathrm{kyr}$ using several proxies obtained from a $7.3 \mathrm{~m}$ long sediment core from the top of the Ceará Rise. We infer Amazonian climate change from fluctuations in the clay mineral assemblage and use down core variations of $\delta^{13} \mathrm{C}$ in the organic carbon fraction and terrigenous sediment supply to the Ceara Rise as indicators of surface circulation changes. Furthermore, we apply vertical planktic foraminiferal $\delta^{18} \mathrm{O}$ gradients and the relative abundances of the phytoplankton species Florisphaera profunda [Kinkel et al., 2000] to trace changes in mixed layer depth.

During the late Quaternary the supply of Amazon River sediment to the Ceará Rise varied strongly, resulting in high glacial and low interglacial accumulation rates of terrigenous matter [Rühlemann et al., 1996; Harris et al., 1997]. Hitherto, Late Cenozoic variations of terrigenous sediment accumulation on the Ceará Rise have been ascribed to various processes, such as sea level fluctuations [Damuth, 1977, Tiedemann and Franz, 1997], redeposition of slope and rise sediments by changes of deepwater circulation [Francois and Bacon, 1991], and variations in surface-ocean circulation [Tiedemann and Franz, 1997] and continental climate [Harris et al., 1997]. The interpretation of terrigenous sediment accumulation rates deduced from Ceará Rise sediment cores, 


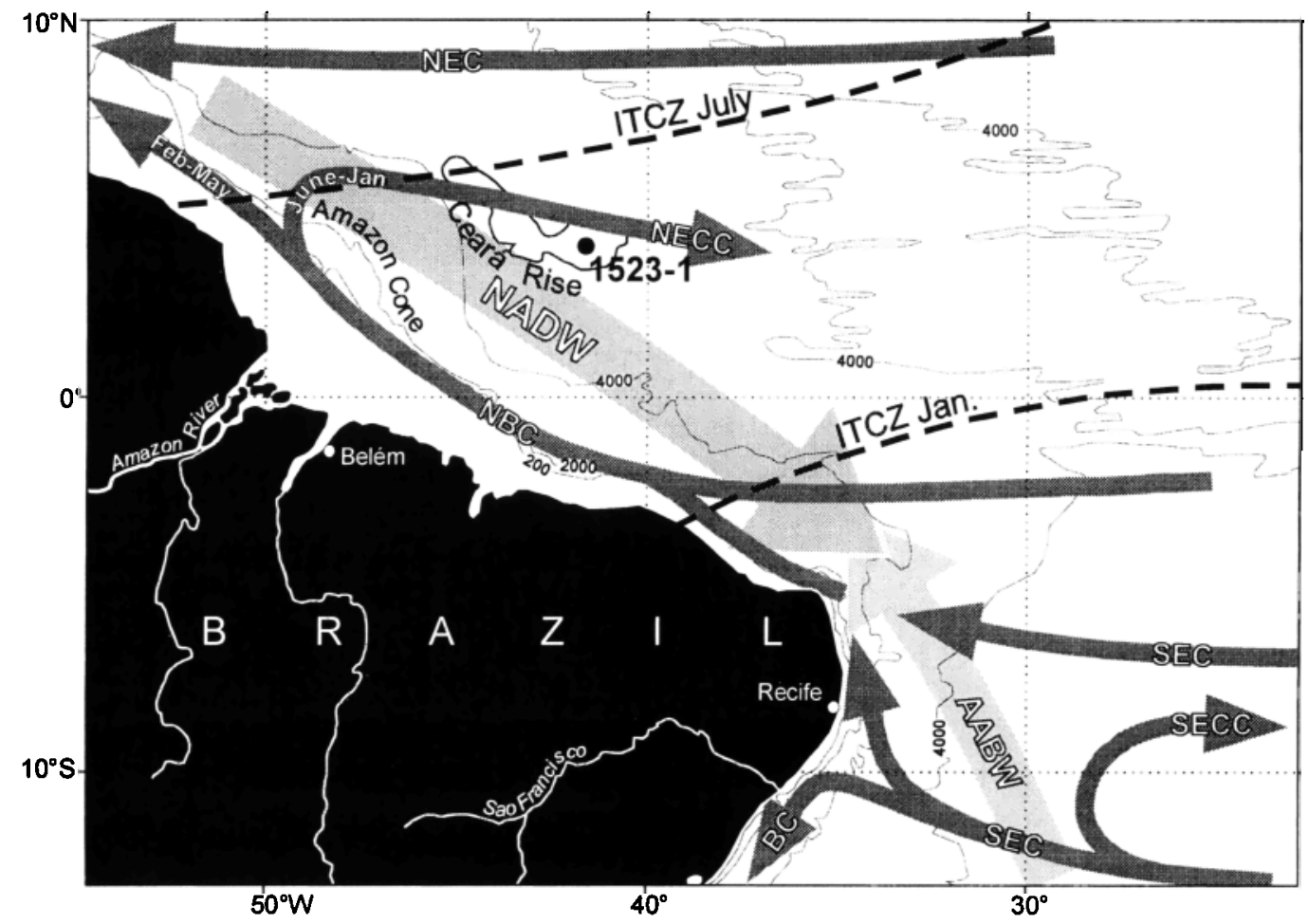

Figure 1. Core location (circle) with bathymetry, surface and deep water circulation, and seasonal positions of the Intertropical Convergence Zone (ITCZ) Surface water currents: SEC, South Equatorial Current; NBC, North Brazil Current; NECC, North Equatorial Counter Current; SECC, South Equatorial Counter Current; BC, Brazil Current. Deep water currents: AABW, Antarctic Bottom Water; NADW, North Atlantic Deep Water.

however, is obscured by difficulties in determining accurate sedimentation rates. Conventional methods of estimating accumulation rates by linear interpolation between dated $\delta^{18} \mathrm{O}$ events may lead to large errors, resulting in an artificial variability of the sedimentation rates, which may become the dominating factor for the variability of accumulation rates, particularly in low-resolution sediments [Verardo and McIntyre, 1994; Frank et al., 1999]. To circumvent this problem, we obtained accumulation rates by normalization to excess ${ }^{230} \mathrm{Th}\left({ }^{230} \mathrm{Th}_{\mathrm{ex}}\right)$ activity. In contrast to methods where accumulation rates are based on linear interpolation, the normalization to ${ }^{230} \mathrm{Th}_{\mathrm{ex}}$ gives more accurate estimates of the paleoflux at each sampled depth and allows a better time resolution.

Variations in the illite/smectite ratio suggest drier climatic conditions in the Amazon lowland during glacials relative to interglacials. We propose that variations of the terrigenous sediment supply from the Amazon mouth to the Ceará Rise are dominated by sea level fluctuations, shelf topography, and changes in the equatorial surface circulation system at orbital periodicities. We ascribe fluctuations in thermocline depth to changes in the southeast trade wind intensity. These changes in trade wind forcing were probably associated with variations in the intensity or annual duration of the NBC retroflection with a more northeastward flow direction of the Amazon's particulate load during cold climatic stages (ice volume maxima).

\section{Regional Setting}

\subsection{Site Location}

Sediment core GeoB 1523-1 was recovered at $3292 \mathrm{~m}$ water depth from the top of the Ceara Rise, which is located in the western tropical Atlantic off the northern coast of South America (Figure 1). The core position $\left(03^{\circ} 49.9^{\prime} \mathrm{N}, 41^{\circ} 37.3^{\prime} \mathrm{W}\right.$ ) is $\sim 1000 \mathrm{~km}$ northeast of the Amazon delta. Marine sediments on the Ceará Rise consist of calcareous oozes and muds with varying proportions of nannofossils (coccolithophorids), foraminifera, and siliciclastic mud [Schulz et al,, 1991]. Biogenic silica and organic carbon together contribute only $<1 \%$ by weight [Rühlemann et al., 1996], and there is no evidence for authigenic or volcanogenic mineral components [Schulz et al., 1991].

\subsection{Oceanographic Setting and Amazon Sediment Transport}

Modern surface circulation in the western equatorial Atlantic is driven by seasonal variations in the intensities of the NE and SE trade winds, which are separated by the Intertropical Convergence Zone (ITCZ). In boreal winter and spring, when the NE trades are strong, the ITCZ lies at its southernmost position (Figure 2e). Concurrently, the NBC flows northwestward along the coast of South America, meets the Guyana Current, and continues into the Caribbean Sea [Richardson and McKee, 1984]. During summer and fall, SE 

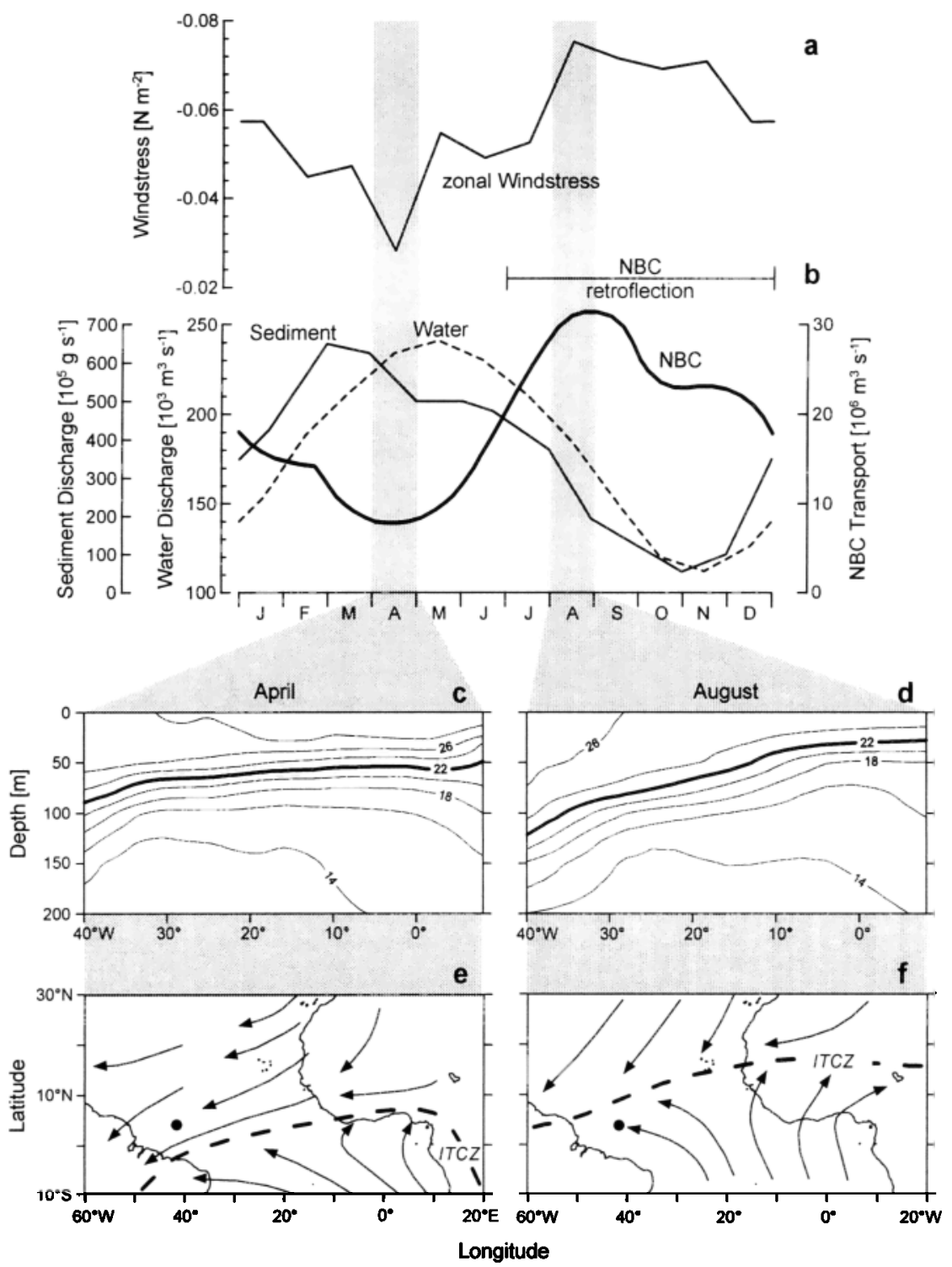

Figure 2. Seasonal variations of wind stress, North Brazil Current transport volume, Amazon discharge, and oceanographic response in the western equatorial Atlantic. (a) Annual cycle of the zonal wind stress (negative to the west, averaged for $5^{\circ} \mathrm{N}-5^{\circ} \mathrm{S}$, $20^{\circ}-60^{\circ} \mathrm{W}$, data are from Picaut et al. [1985]). (b) Sediment and water discharge of the Amazon River and NBC transport volume [after Nittrouer and DeMaster, 1996]. Seasonal contrast of the isotherm depths on an E-W profile at the equator for (c) April and (d) August; data are from Levitus and Boyer [1994]. Seasonal position of the Intertropical Convergence Zone (ITCZ) and change of the trade wind pattern for (e) April and (f) August, circles mark the position of core GeoB 1523-1

trade winds strengthen, and the ITCZ moves to the north (Figure 2f). The increased zonal wind intensity (Figure 2a) results in a deepening of the thermocline in the western equatorial Atlantic (Figure 2d) due to the pileup of surface waters that are transported westward with the SEC [Hastenrath and Merle, 1987] (Figure 2d). Owing to the strong W-E pressure gradient, the eastward-flowing NECC develops [Hastenrath, 1996]. Drifter buoy and satellite pigment data reveal that between June and January, the NBC detaches from its confined flow along the Brazilian coast at $\sim 5^{\circ} \mathrm{N}$ and turns eastward into the NECC [Richardson and Reverdin, 1987; Miller-Karger et al., 1988].
Most of the suspended sediment discharged by the Amazon River accumulates on the shelf [Kuehl et al., 1986], whereas $7-17 \%$ of it is carried northwestward along the South American coast within the fast flowing NBC [Kineke et al., 1996; Nittrouer et al., 1986] that reaches current velocities of $>100 \mathrm{~cm} \mathrm{~s}^{-1}$ [Richardson and Reverdin, 1987; Schott et al., 1995]. A maximum of $5 \%$ of the Amazon's particulates $(<0.6$ $\mathrm{x} 10^{8}$ tons $\mathrm{yr}^{-1}$ ) is advected offshore in a low-salinity surface plume [Kineke et al., 1996] and probably reaches the NBC retroflection. Analysis of historical salinity data indicates that between August and October, when NBC transport and retroflection are strongest (Figure $2 \mathrm{~b}$ ), nearly $70 \%$ of the 


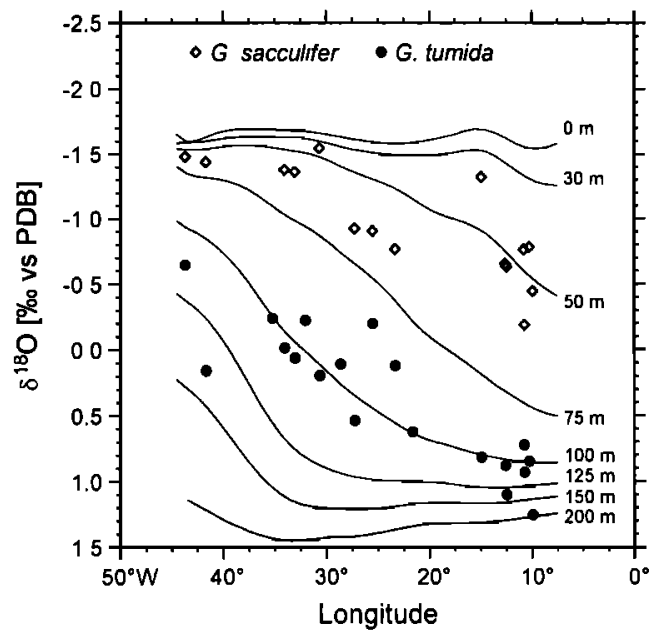

Figure 3. Predicted $\delta^{18} \mathrm{O}$ of calcite precipitated in equilibrium with seawater at different depths and measured $\delta^{18} \mathrm{O}$ values of Globorotalia tumida and Globigerinordes sacculifer (without saclıke final chamber) from core tops on an equatorial transect between $10^{\circ}$ and $45^{\circ} \mathrm{W}$ We calculated the predicted $\delta^{18} \mathrm{O}$ of calcite using annual mean temperature and salınity observations from Levitus and Boyer [1994], an empırıcal regional salinity- $\delta^{18} \mathrm{O}$ calibration for the tropical Atlantic [Paul et al, 1999], and the paleotemperature equation of Shackleton [1974] The $\delta^{18} O$ values of $G$ sacculifer were corrected for a disequilibrium shift of $04 \%$ (see text).

Amazon plume water is carried eastward in the NBC retroflection [Lentz, 1995].

\section{Methods}

\subsection{Analysis}

3.1.1. Sampling. Sediment core GeoB 1523-1 was recovered with a gravity corer during Cruise M16/2 of the Research Vessel Meteor in 1990 [Schulz et al., 1991]. On board the ship, sediment samples for the determination of carbonate content, physical properties, and stable isotope analysis were taken in $5 \mathrm{~cm}$ intervals (representing time steps between 1 and $5 \mathrm{kyr}$ ). Later, at the University of Bremen, further samples were taken for clay mineral and grain size analysis at $5 \mathrm{~cm}$ intervals and for ${ }^{230} \mathrm{Th}$ measurements at 10 $\mathrm{cm}$ intervals.

The data of terrigenous sediment (noncarbonate) contents, stable isotope ratios of total organic carbon $\left(\delta^{13} \mathrm{C}_{\text {TOC }}\right)$, and ${ }^{230} \mathrm{Th}_{\mathrm{ex}}$ activity are published by Ruihlemann et al [1996], where analytical methods are reported in detail. Grain size separation and clay mineral analyses followed standard techniques described by Petschick et al. [1996].

3.1.2. Stable oxygen isotopes. Stable oxygen isotopes of 15-30 specimen of the planktic foraminiferal species Globorotalia tumida (size of $600 \mu \mathrm{m}$ ) and Globigerinoides sacculifer (size of $350-400 \mu \mathrm{m}$ ) were measured with a Carousel-48 automatic carbonate preparation system attached to a Finnigan MAT-251 mass spectrometer. Calibration of the laboratory-internal standard gas to the Pee dee belemnite (PDB) standard was made through the NBS-18, NBS-19, and
NBS-20 standards. Analytical precision based on replicate analyses of an internal standard was better than $\pm 0.07 \%$.

3.1.3. Accumulation rates of terrigenous sediment. Accumulation rates of terrigenous sediment $\left(\mathrm{AR}_{\text {terr }}\right)$ were calculated by normalization to excess ${ }^{230} \mathrm{Th}\left({ }^{230} \mathrm{Th}_{\mathrm{ex}}\right)$ activities [cf. Rühlemann et al., 1996]. This method is based on the uniform distribution of dissolved Uranium in the oceans and thus well-known production rate of ${ }^{230} \mathrm{Th}$ in the water column. Because of its very low residence time and high particle reactivity the flux of ${ }^{230} \mathrm{Th}$ to the seafloor is expected to match its local production rate, which is assumed to have been constant within the past $500 \mathrm{kyr}$. The ${ }^{230} \mathrm{Th}_{\mathrm{ex}}$ activities (decay corrected to the time of deposition) thus can be used as a reference against which the accumulation rate of any other sedimentary component can be estimated [Bacon, 1984; Francois et al, 1990].

3.1.4. The ${ }^{230} \mathrm{Th}_{\mathrm{ex}}$ mass balance. The focusing factor $\Psi$ for sediments indicates the extent to which ${ }^{230} \mathrm{Th}_{\mathrm{ex}}$ was supplied by postdepositional redistribution and lateral advection. For this estimation the amount of ${ }^{230} \mathrm{Th}_{\mathrm{ex}}$ that accumulated within a certain depth interval of sediment is compared with the amount of ${ }^{230} \mathrm{Th}_{\text {ex }}$ produced in the overlying water column during the time interval of sediment deposition [Francois et al, 1990; Frank et al, 1999].

\subsection{Thermocline Reconstruction}

The $\delta^{18} \mathrm{O}$ difference $\left(\Delta \delta^{18} \mathrm{O}\right)$ between shallow- and deepdwelling planktic foraminifera is a proxy for the stratification of surface waters [Ravelo and Fairbanks, 1992; Mulitza et al., 1997; Billups et al., 1999]. In environments with deep mixed layers such as the western equatorial Atlantic the temperature gradient and hence the vertical $\Delta \delta^{18} \mathrm{O}$ is relatively small, whereas it is relatively large when mixed layer depth is as shallow as in the eastern equatorial Atlantic. In Figure 3 we plotted predicted $\delta^{18} \mathrm{O}$ of calcite at water depths between 0 and $200 \mathrm{~m}$ together with measured $\delta^{18} \mathrm{O}$ values of $G$. tumida and $G$. sacculifer (without saclike final chamber) from core tops on a transect along the equator. The $\mathrm{E}-\mathrm{W}$ decrease of predicted $\delta^{18} \mathrm{O}$ (axis inverted) at depths between 50 and $150 \mathrm{~m}$ mainly originates from the difference of vertical temperature gradients in the eastern and western tropical Atlantic and hence reflects an annual average of the seasonal thermocline slopes (see Figures $2 \mathrm{c}$ and $2 \mathrm{~d}$ ). In accordance with previous publications [Schweitzer and Lohmann, 1991; Ravelo and Fairbanks, 1992], $\delta^{18} \mathrm{O}$ values of $G$. tumida indicate average calcification depths around $100 \mathrm{~m}$ (upper to middle seasonal thermocline), assuming that the shells are precipitated in isotopic equilibrium with seawater [Williams et al., 1981], whereas $G$. sacculifer calcifies in the mixed layer and upper seasonal thermocline. We corrected $G$. sacculifer for an average $\delta^{18} \mathrm{O}$ disequilibrium shift of $-0.4 \%$ (with respect to the paleotemperature equation of Shackleton [1974]) as determined from living specimens caught from surface waters at the Ceará Rise region (S. Mulitza, unpublished data, 1998). Because of the different calcification depths, $\Delta \delta^{18} \mathrm{O}$ between $G$ sacculifer and $G$. tumida provides a measure of the vertical temperature gradient and hence of mixed layer depth and thermocline. 

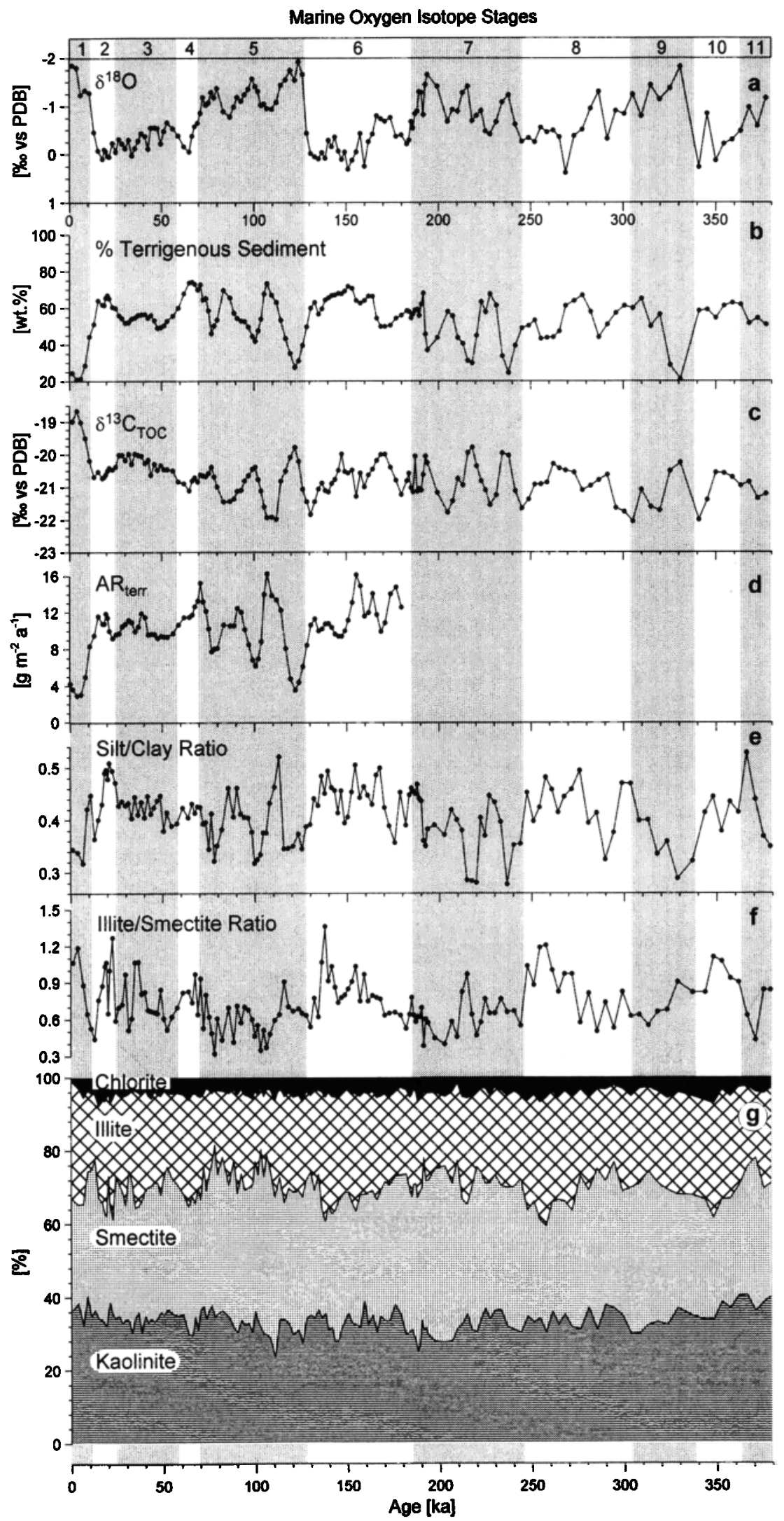

Figure 4. Time series of proxy data for core GeoB 1523-1 comprising (a) oxygen isotope composition of the planktic foramınıferal species $G$ sacculifer for stratigraphic control, (b) weight percentages of the terrigenous sediment fraction, (c) ${ }^{13} \mathrm{C} /{ }^{12} \mathrm{C}$ ratios of total organic carbon, (d) ${ }^{230} \mathrm{Th}_{\mathrm{cr}}$-normalized accumulation rates of terrigenous matter $\left(\mathrm{AR}_{\mathrm{ter}}\right)$, (e) silt/clay ratios of the terrigenous silt fraction, ( $f$ ) 1 llite/smectite ratios, and (g) proportions of clay mineral groups. 


\section{SMECTITE}

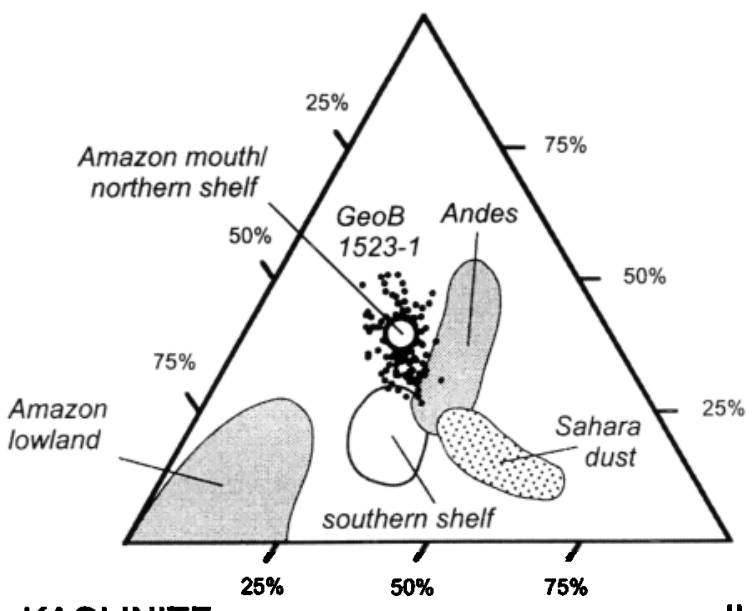

KAOLINITE

ILLITE

Figure 5. Clay mineral composition of core GeoB 1523-1 (dots represent individual measurements of each sample) and of potential sources for the supply of terrigenous sediment to the Ceará Rise (clusters).

\section{Results and Discussion}

\subsection{Proxy Records}

Time series of the various proxy data of sediment core GeoB 1523-1 are presented in Figure 4. The age model is based on the correlation of the planktic foraminiferal $\delta^{18} \mathrm{O}$ record of $G$. sacculifer (Figure 4a) with the SPECMAP standard stack [Imbrie et al., 1984] and is published by Rühlemann et al. [1996]. Terrigenous sediment contents (Figure 4b) almost perfectly mirror the oxygen isotope record of $G$. sacculifer with low percentages during $\delta^{18} \mathrm{O}$ minima and high percentages during $\delta^{18} \mathrm{O}$ maxima. Down core variations of $\delta^{13} \mathrm{C}_{\text {TOC }}$ (Figure $4 \mathrm{c}$ ) also exhibit a pronounced cyclicity with maximum values during $\delta^{18} \mathrm{O}$ minima and vice versa. Because of the different end-member $\delta^{13} \mathrm{C}$ values for marine $(-21 \%)$ and terrestrial organic carbon $(-27 \%)$ the $\delta^{13} C_{\text {TOC }}$ record of core GeoB 1523-1 serves as a proxy for changes in terrestrial organic carbon supply to the Ceara Rise [cf. Rihlemann et al., 1996]. The ${ }^{230} \mathrm{Th}_{\mathrm{ex}}$-normalized accumulation rates of terrigenous sediment (Figure 4d) closely resemble the record of terrigenous sediment contents. Silt/clay ratios (Figure 4e) are relatively high during glacial maxima and during cold substages, when proportions and accumulation rates of the terrigenous sediment fraction are increased. Temporal clay mineral variability (Figure $4 \mathrm{~g}$ ) is of low amplitude and mainly concerns countervarying proportions of illite and smectite (displayed by fluctuations of illite/smectite ratios; Figure $4 \mathrm{f}$ ), which do not show a significant covariation with the proxy data mentioned above. On average, the clay mineral suite reveals approximately equal proportions of smectite $(37 \%)$, illite $(26 \%)$, and kaolinite $(33 \%)$ with a minor chlorite content $(4 \%)$.

\subsection{Provenance of Terrigenous Sediment}

Three potential sources of terrigenous sediment have to be considered for the Ceará Rise: (1) the particulate sediment load of the Amazon River, (2) resuspended material of the North Brazilian shelf and slope, and (3) dust particles from African deserts supplied by trade winds. The proximity of the Ceará Rise to the Amazon delta and the enormous amounts of sediment discharged by the Amazon suggest that waters of the Amazon River are the main contributors of siliciclastics to the Ceara Rise. Actually, the clay mineral assemblage found in core GeoB 1523-1 is almost identical to the clay mineral composition of suspensions and sediments from the Amazon mouth and adjacent shelf sediments to the north [Gibbs, 1967; Baretto et al., 1975] (Figure 5). Shelf sediments south of the Amazon River mouth reveal lower smectite abundances than the Amazon sediment load [Barreto et al., 1975]. The clay mineral composition of Ceará Rise sediments also rules out any significant dust input from the southern Sahara and the Sahel zone through NE trade winds, from where dust particles are dominated by illite and depleted in smectite [Delany et al., 1967; Chester et al., 1972; Aston et al., 1973]. As well, dust influx by SE trade winds is very unlikely because dust loadings in the SE trades are magnitudes lower than in the NE

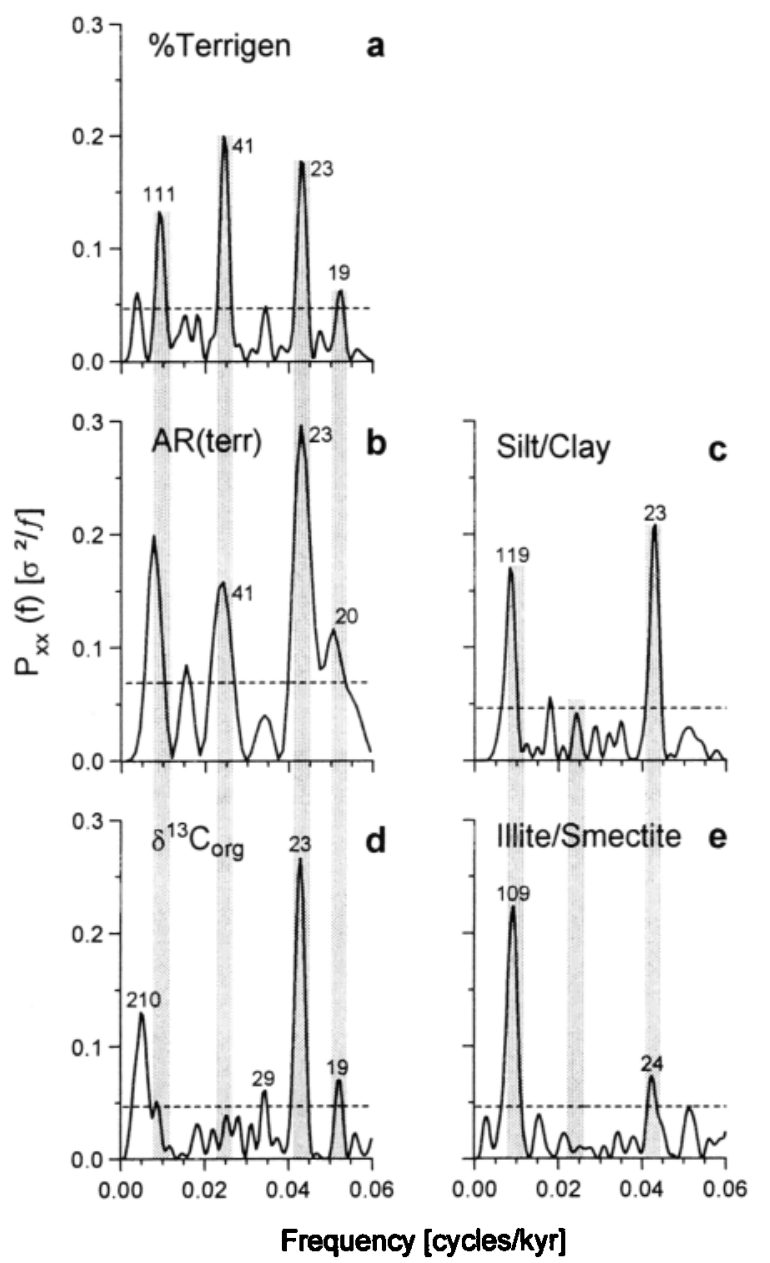

Figure 6. Harmonic amatysss of uneventy spaced tme series using the SPECTRUM software [Schulz and Stattegger, 1997]. Periodic components that exceed the dashed lines (Stegel's test) are regarded to be significantly present in the tıme series. Numbers above peaks denote respective periods. Settıngs for all tests $\mathrm{OFAC}=8, \mathrm{HIFAC}=1, \alpha=$ 005 , and $\lambda=0.4$ 

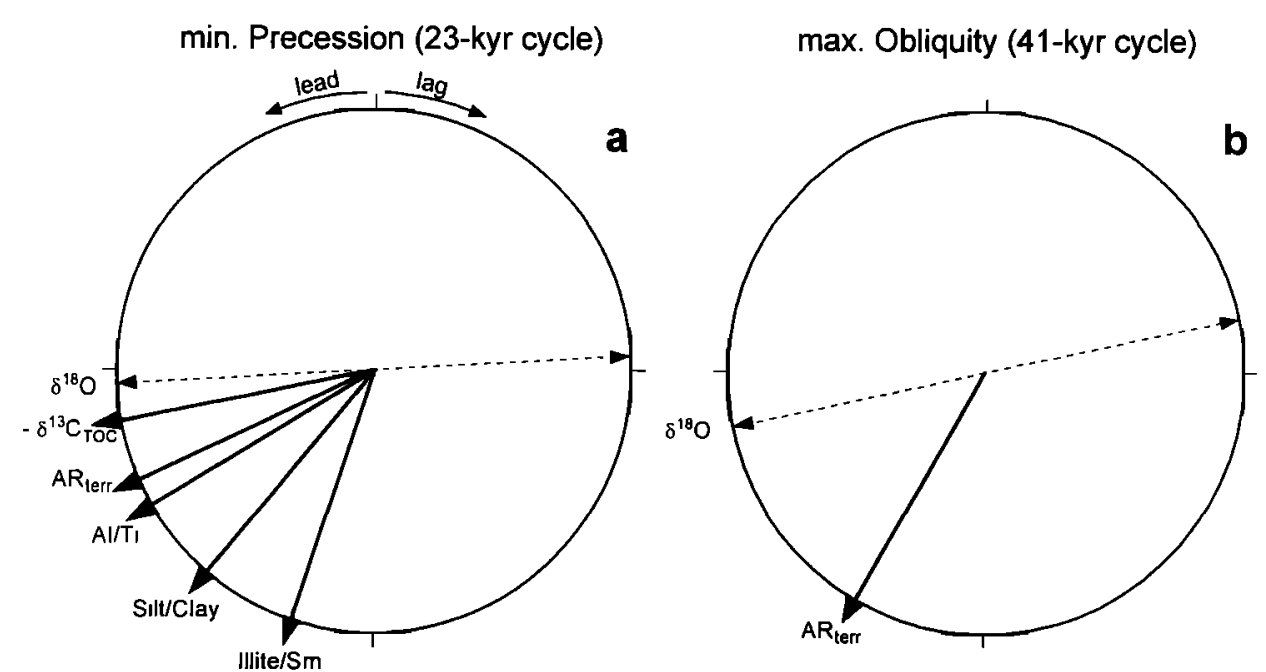

max. Eccentricity (100-kyr cycle)

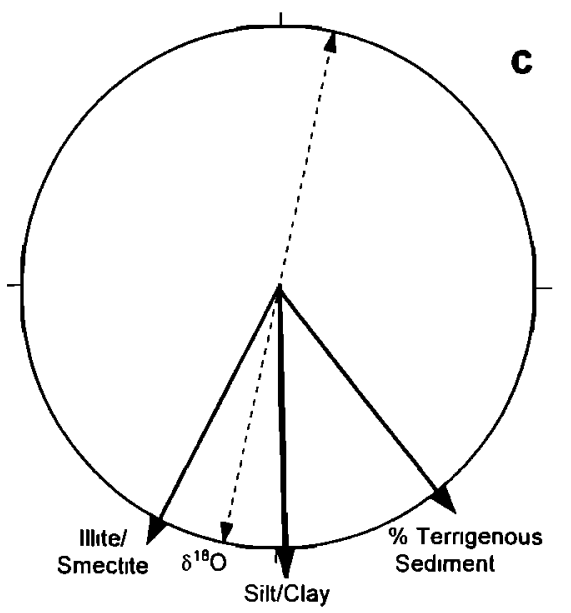

Figure 7. Phase relatıonshıps between sedımentary tıme serıes of $\delta^{13} \mathrm{C}_{\mathrm{TOC}}$ (reversed), ${ }^{230} \mathrm{Th}_{\mathrm{ex}}$-normalızed accumulatıon rates of terrigenous sedıment $\left(\mathrm{AR}_{\mathrm{terr}}\right)$, aluminum/tıtan ratıos [Zabel et al, 1999], sil/clay ratıos, illıte/smectıte ratıos, and percent terrigenous sediment with respect to the $G$. sacculffer $\delta{ }^{18} \mathrm{O}$ record for the periods of precession, obliquity, and eccentricity according to the SPECMAP convention [Imbrie et al, 1989] Counterclockwise displacements indicate lead in degrees The $\delta^{18} \mathrm{O}$ of $G$ sacculifer from core GeoB $1523-1$ indicates maxımum ice volume and mınımum sea level

trades [Chester et al, 1972]. Down core variations of Al/Ti ratios in sediment core GeoB 1523-1 likewise indicate that detrital supply from African sources was not significant during the past $380 \mathrm{kyr}$ [Zabel et al,, 1999]. Hence terrigenous sediments on the Ceará Rise almost exclusively originate from the discharged sediment load of the Amazon River.

The major sources of particles transported by the Amazon River are weathering products of the Andes, the Guyana and Brazilian shields, and the Amazon Basin. At present, most of the detritus is delivered by the upstream tributaries and originates from erosion and physical weathering of rocks in the Peruvian and Bolivian Andes [Gibbs, 1967; Milliman and Meade, 1983]. Only a small proportion of detritus is derived from the low land region, which represents by far the greater part of the Amazon's catchment area and which is characterized by chemical weathering conditions. A predominance of Andean debris in the terrigenous fraction of core
GeoB $1523-1$ is also suggested by the relative proportions of the rock-derived clay mineral, illite (and subordinate chlorite), and the soil-derived clay minerals, kaolinite and smectite (Figure 5), indicating highland or lowland provenance, respectively [Gibbs, 1967; Debrabant et al, 1997]. Kaolinite generally reflects full humid conditions, whereas smectite is predominately formed in semihumid regions [Chamley, 1989].

\subsection{Amazonian climate}

The low amplitude of the down core clay mineral variations (Figure $4 \mathrm{~g}$ ) suggests a relatively constant provenance of the terrigenous matter supplied to the Ceará Rise during the past $380 \mathrm{kyr}$. In contrast to the other proxies, the illite/smectite ratio exhibits a pronounced dominance at the $1 / 100 \mathrm{kyr}^{-1}$ frequency and only weak power in the $1 / 23 \mathrm{kyr}^{-1}$ frequency band (Figure 6e). Fluctuations in total siliciclastic input at Ceará Rise lead ice volume by $14 \mathrm{kyr}$ at the $1 / 100 \mathrm{kyr}^{-1}$ band (Figure $7 \mathrm{c}$ and Table 1). This clearly suggests no link between 
Table 1. Results of Cross-Spectral Analysis ${ }^{\mathrm{a}}$

\begin{tabular}{|c|c|c|c|c|c|c|c|c|}
\hline & \multicolumn{2}{|c|}{$1 / 100 \mathrm{kyr}^{-1}$ Band } & \multicolumn{2}{|c|}{$1 / 41 \mathrm{kyr}^{-1}$ Band } & \multicolumn{2}{|c|}{$1 / 23 \mathrm{kyr}^{-1}$ Band } & \multirow{2}{*}{$\begin{array}{c}T, \\
\mathrm{kyr}\end{array}$} & \multirow{2}{*}{$\begin{array}{l}\Delta l, \\
\mathrm{kyr}\end{array}$} \\
\hline & k & $\emptyset$ & $k$ & $\theta$ & $k$ & $\varnothing$ & & \\
\hline Percent terr & 099 & $-51 \pm 4(-14.2)$ & 097 & $-52 \pm 8(-59)$ & 0.99 & $-17 \pm 5(-1.1)$ & 377 & 26 \\
\hline $\mathrm{Ar}_{\text {terr }}$ & $\mathrm{nc}$ & --- & 0.91 & $-48 \pm 9(-5.5)$ & 098 & $-22 \pm 6(-1.4)$ & 180 & 2.0 \\
\hline$-\delta^{13} \mathrm{C}_{\text {TOC }}$ & n.c & -- & $\mathrm{nc}$. & --- & 0.96 & $-5 \pm 8(-0.5)$ & 377 & 2.6 \\
\hline Silt/clay & n.c & --- & n.c. & $\cdots$ & 0.96 & $-46 \pm 8(-2.9)$ & 379 & 2.6 \\
\hline Illite/smectite & 0.97 & $15 \pm 8(4.2)$ & n.c. & $\cdots$ & 0.90 & $-69 \pm 15(-4.4)$ & 379 & 2.6 \\
\hline $\mathrm{Al} / \mathrm{Ti}$ & $\mathrm{n} \mathrm{c}$ & --- & n.c. & $\ldots$ & 095 & $-28 \pm 8(-1.8)$ & 377 & 2.7 \\
\hline
\end{tabular}

"Phasing with respect to the Globigerinotdes sacculifer $\delta^{18} \mathrm{O}$ record of core GeoB 1523-1 The $k$ denotes coherency, and $\emptyset$ is the phase difference in degree (kyr) with $80 \%$ confidence interval where negative (positive) values indicate lead (lag) with respect to $\delta^{18} \mathrm{O}$; n.c. indicates no significant coherency, $T$ is the length of the time series, and $\Delta t$ is the average sample interval. Cross-spectral analyses were performed using Welch's [1967] overlapped segment average (WOSA) procedure with two overlapping segments and a Welch window

sea level variations and terrigenous sediment supply, and therefore it is not very likely that the variability in clay minerals is controlled by sea level fluctuations, Instead, clay mineralogy is apparently related to nonmarine environmental changes within the continental source region.

Changes in clay mineralogy most likely reflect tropical climate variability. Variations in temperature and precipitation may alter modes of weathering and the fluvial water budget. Illite/smectite ratios in core GeoB 1523-1 indicate an increase in the relative amount of detrital illite and/or a decrease of the pedogenic clay mineral smectite during glacial times and cold substages of interglacials. A higher supply of illite-rich debris may have been caused by a more humid climate than today, which would augment rainfalls and water runoff from the Andean tributaries of the Amazon River and thus increase fluvial transport of illite-bearing detritus from the highland regions. A reduced accumulation of smectite, on the other hand, could be attributed to a less extensive chemical weathering in the Amazon lowland, especially in the marginal semihumid regions. This latter scenario is the more probable one since a drier and cooler climate in the Amazon basin during the last glacial is indicated by several proxies, such as mineralogical maturity of arcosic arenites in the Guyana Basin and on the Amazon shelf [Damuth and Fairbridge, 1970; Milliman et al., 1975], air temperatures reconstructed from noble gases in lowland Brazilian groundwater [Stute et al, 1995], and marine and continental pollen records [van der Hammen and Absy, 1994; Haberle and Maslin, 1999] and iron oxide concentrations in Ceará Rise sediments [Harrıs and Mix, 1999]. In deposits of the Amazon Fan, Debrabant et al [1997] likewise found low smectite concentrations in sediments of the last glacial period, which they explained to reflect a less intense chemical weathering and drier climate in the Amazon catchment area. Also in the subtropical realm of southern Brazil a drier continental climate than today prevailed during glacial times, as indicated by clay mineral proxies in marine sediment cores from the Vema Channel region [Gingele et al, 1999].

The clay mineralogical evidence of core GeoB 1523-1 suggests that tropical climate changes in South America, which have markedly affected the continental environment in terms of soil formation and climate zonation, mainly vary with a $1 / 100 \mathrm{kyr}^{-1}$ frequency (Figure 6e). This dominant $100 \mathrm{kyr}$ climate cyclicity in tropical South America is also postulated for the Pliocene and older Pleistocene on the basis of sedimentary climate records from the adjacent Pacific and Atlantic Oceans [Mix et al, 1995; Harris et al, 1997; Harris and Mix, 1999]. Harris and Mix [1999] deduced climate changes from Amazon lowland iron oxides and oxyhydroxides and explained the strong $100 \mathrm{kyr}$ precipitation cycles by latitudinal shifts of the ITCZ driven by nonlinear amplification of insolation forcing at precessional frequencies. They observed that maximum humidity occurred $\sim 11 \mathrm{kyr}$ before minimum ice volume, whereas illite/smectite ratios in this study point to a $4 \mathrm{kyr}$ lag (Figure $7 \mathrm{c}$ and Table 1). This discrepancy in phase is probably due to our relatively short time series of only $380 \mathrm{kyr}$. The precessional component of our illite/smectite ratio (Figure 7a), however, is in phase within error limits with the precipitation index of Harris and Mix [1999].

In summary, compositional variations of clay minerals in core GeoB 1523-1 are related to changes of weathering conditions in the Amazon's catchment area. Amazonian climate was dominated by a strong $100 \mathrm{kyr}$ and a subordinate 23 kyr cyclicity with drier conditions during glacials, in particular in the lowlands of the Amazon Basin. In turn, as discussed in the following sections, variations of fluxes and modes of terrigenous sediment supply to the Ceará Rise seem to be related to oceanographic and atmospheric processes that vary in tune with orbital forcing predominately with a precessional periodicity.

\subsection{Mode of Terrigenous Sediment Transport to the Ceará Rise}

The quantification of sediment redistribution during the past $180 \mathrm{kyr}$ mainly yields ratios close to unity between expected and measured flux of ${ }^{230} \mathrm{Th}_{\mathrm{ex}}$ to the sediment (Figure 8). This indicates that vertical particle settling from the overlying water column dominated sediment accumulation [Francois and Bacon, 1991] and that neither winnowing nor 


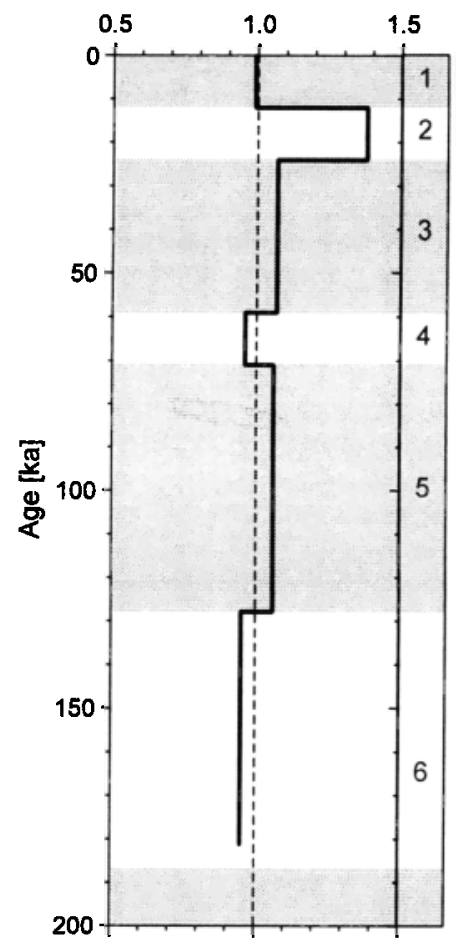

Figure 8. The ${ }^{230} \mathrm{Th}$ mass balance for core GeoB 1523-1. Values close to 1 indicate that postdepositional redistribution and lateral transport of sediment to the core site were small during the past $180 \mathrm{kyr}$

bottom current-induced sediment supply to the top of the Ceará Rise occurred. Only during MIS 2, the burial of ${ }^{230} \mathrm{Th}_{\mathrm{ex}}$ in the sediment significantly exceeded the production in the water column $(\Psi=1.38)$, suggesting that some $40 \%$ of the ${ }^{230} \mathrm{Th}_{\mathrm{ex}}$ (and thus of the siliciclastics) originated from lateral redistribution processes. Turbidites detached from the Amazon Fan cannot have directly approached the core site of GeoB 1523-1, which is located $>1 \mathrm{~km}$ above the abyssal plain (Figure 9a). Some of the fine fraction suspended from these turbidites, however, was probably advected within deepwater masses to the core site [Francois et al, 1990] and may account for the slightly increased $\Psi$ value during MIS 2 .

Since terrigenous matter on the Ceará Rise almost exclusively originates from the Amazon's particulate load and mainly reaches the core site within the upper water column, the most likely transport mechanism to the top of the rise is within the freshwater plume discharged at the Amazon mouth. Observations of modern tropical Atlantic surface hydrography have shown that the offshore flow of the freshwater plume is directed by the ocean's surface circulation and can reach the Ceará Rise during northern summer [Cochrane, 1969; Dessier and Donguy, 1994]. Most of the entrained clay and finegrained silt particles are held in suspension as long as the freshwater plume is not diluted by salty ocean water that initiates particle flocculation and differential settling [e.g., Chamley, 1989]. Therefore changes in the amount and grain size of terrigenous sediment delivered to the Ceará Rise depend on how near and how fast the plume has approximated the rise during the late Quaternary. It is reasonable to assume that a direct approach of the plume core above the Ceará Rise delivers more and coarser terrigenous material than do marginal runners from a distant plume. Hence greater silt/clay ratios during low sea levels (Figure $4 \mathrm{e}$ ) indicate a reduced transport distance of the Amazon particulates to Site GeoB 1523 and/or an increased current speed relative to sea level highstands, suggesting changes of western equatorial Atlantic circulation system, in particular, with a precessional cyclicity.

\subsection{Causes for Fluctuations in Terrigenous Sediment Accumulation}

Changes in the amount of Amazon-derived siliciclastics supplied to the Ceará Rise have three main possible causes: (1) fluctuations in the Amazon's sediment discharge, (2) glacioeustatic sea level variations, or (3) changes in the offshore flow direction of the Amazon's freshwater plume.

1. Fluctuations in the Amazon's water discharge and the associated concentration of suspended particles are controlled by climatic variations in the catchment area. However, as pointed out in section 4.3, glacial periods in Amazon lowland were apparently drier than interglacials. Therefore, chemical weathering and terrigenous particle supply to the Ceará Rise would have been diminished rather than increased. Moreover, climatic changes that affect the terrestrial environment, documented in the illite/smectite ratio, have different phase relationships to $\delta^{18} \mathrm{O}$ (Figure 7) than the terrigenous matter deposition on the Ceará Rise. Thus changes in Amazon water runoff as a forcing mechanism of terrigenous particle supply to the Ceará Rise are unlikely.

2. The time series of $A R_{\text {terı }}$ and $\delta^{13} \mathrm{C}_{\mathrm{TOC}}$ of core $\mathrm{GeoB}$ 1523-1, which are dominated by precessional periodicity, are nearly in phase at the $23 \mathrm{kyr}$ cycle with the $\delta^{18} \mathrm{O}$ record of $G$. sacculifer that we used as an indicator of global ice volume and eustatic sea level (Figure $7 \mathrm{a}$ and Table 1). The phase relationship suggests that the delivery of Amazon suspensates to the top of the Ceará Rise has been primarily controlled by sea level fluctuations. When sea level dropped, the Amazon estuary moved northward by up to $350 \mathrm{~km}$ and approached the shelf edge (Figure 9a). The fluvial sediment load, which is stored on the inner shelf during highstands of sea level, then reaches the deep sea directly and builds up the Amazon Fan [Damuth, 1977]. Schneider et al. [1997] determined a threshold sea level fall of $40-50 \mathrm{~m}$, below which terrigenous input dominated the deposition on the continental slope. Terrigenous sediment accumulation on the Ceará Rise, however, is not simply a linear function of sea level fluctuation. Otherwise, the deposition of terrigenous matter should be dominated by glacial-interglacial cycles in the $1 / 100 \mathrm{kyr}^{-1}$ frequency band, which is the strongest signal of late Quaternary ice volume and sea level variations [Imbrie et al., 1984]. Instead, precessional cyclicity, only a minor component of ice volume fluctuations, is the most prominent signal in our proxy records (Figure 6). Moreover, the greatest amplitudes in the time series of $\mathrm{AR}_{\text {terr }}$ and $\delta^{13} \mathrm{C}_{\mathrm{TOC}}$ do not appear at the terminations when sea level quickly rose by $>100 \mathrm{~m}$ but at the transitions from marine oxygen isotope substages 5.5 to 5.4 and 5.4 to 5.3 when sea level dropped by $50 \mathrm{~m}$ and increased by $15 \mathrm{~m}$, respectively (Figures $10 \mathrm{a}$ and $10 \mathrm{c}$ ).

The predominance of precessional variations in the proxy records of terrigenous matter supply (Figures 6a-6d), most 


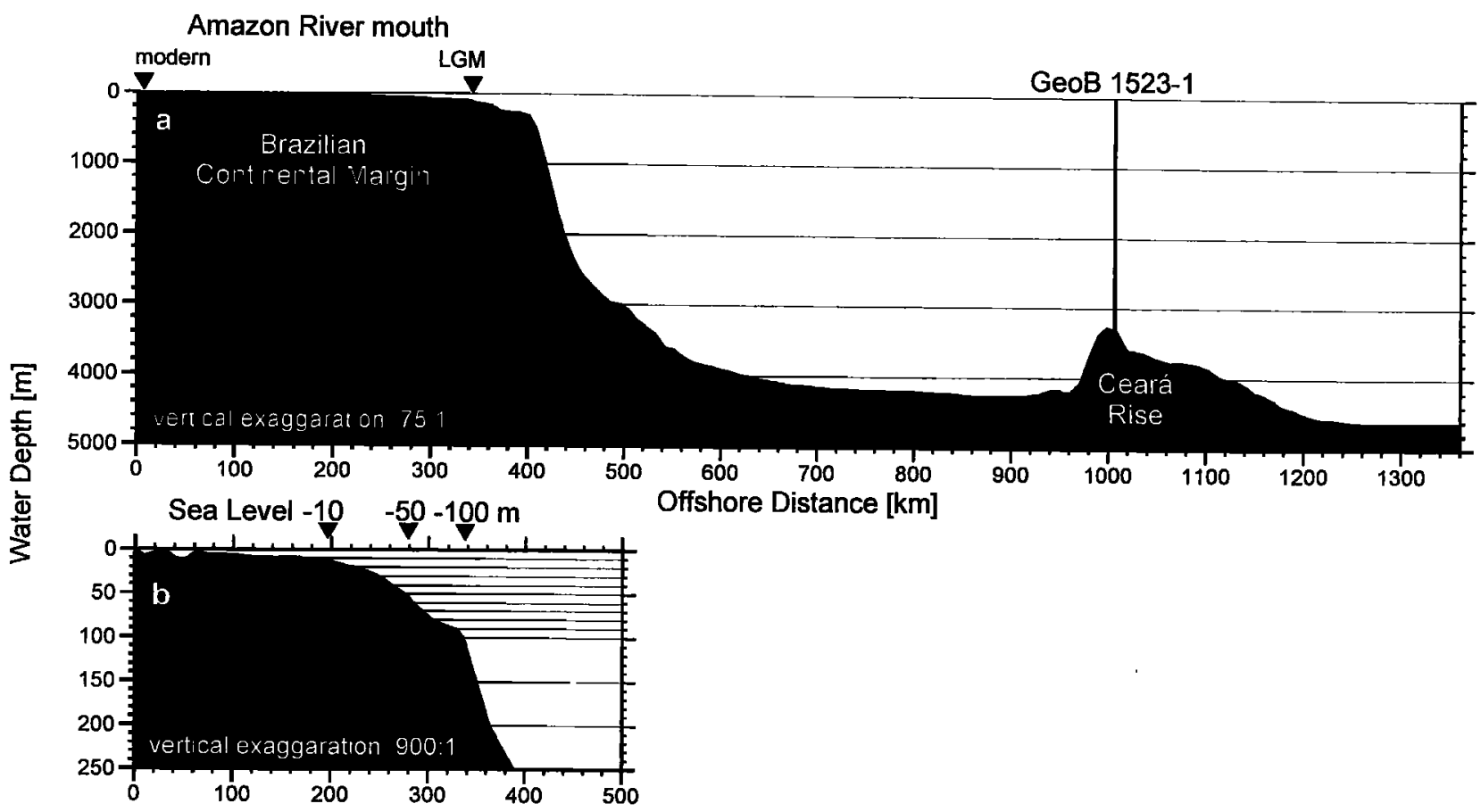

Figure 9. (a) Topographic profile extending from the modern Amazon River mouth to the Ceara Rise The location of the river mouth durıng the Last Glacial Maximum and the position of core GeoB 1523-1 are indicated. (b) Strongly exaggerated profile of the shelf off the Amazon mouth with the locations of the river mouth after drops of sea level by 10,50 , and $100 \mathrm{~m}$, respectively

pronounced during interglacials (Figures $4 \mathrm{~b}-4 \mathrm{e}$ ), can be explained by the topography of the shelf off the Amazon estuary. The shelf is characterized by only minor sloping from the coast out to $10 \mathrm{~m}$ water depth over a distance of $\sim 200 \mathrm{~km}$ (Figure 9b). Thus the lowering of the sea level by $50 \mathrm{~m}$ after the highstand during marine oxygen isotope substage 5.5 moved the coast line and the river mouth far north and subaerially exposed a large area of the shelf to erosion during substage 5.4. Concomitantly, the Amazon's sediment load was guided directly to the fan by a shelf-cutting canyon with its upper end $\sim 40 \mathrm{~m}$ below the present sea level [Milliman et al., 1975]. During the following sea level rise from substages 5.4 to 5.3 by only $\sim 15 \mathrm{~m}$ the terrigenous matter accumulation at the Amazon Fan and the Ceará Rise was strongly reduced (Figure 10), and the sediment load again was deposited on the shelf. Consequently, the supply of terrigenous sediment to the Ceará Rise is very susceptible to sea level oscillations varying between the present level and 40-50 $\mathrm{m}$ lower than today, whereas it is less sensitive to changes in sea level $>50 \mathrm{~m}$ lower than today. For this reason, the amplitude of variations in sediment accumulation is higher during interglacials than during glacials (Figure 4d).

3. The strongly increased transport of terrigenous particles to the Ceará $R$ ise in the upper water column during decreasing sea level furthermore requires a change of the surface circulation system in the western equatorial Atlantic. A circulation pattern similar to the modern one, with a fastflowing along-shelf NBC that reaches depths of $\sim 1 \mathrm{~km}$ [Schott et al., 1995], still would have carried the bulk of the Amazon suspensates northwestward to the Caribbean. We thus suppose that during times of sea level lowering the NBC

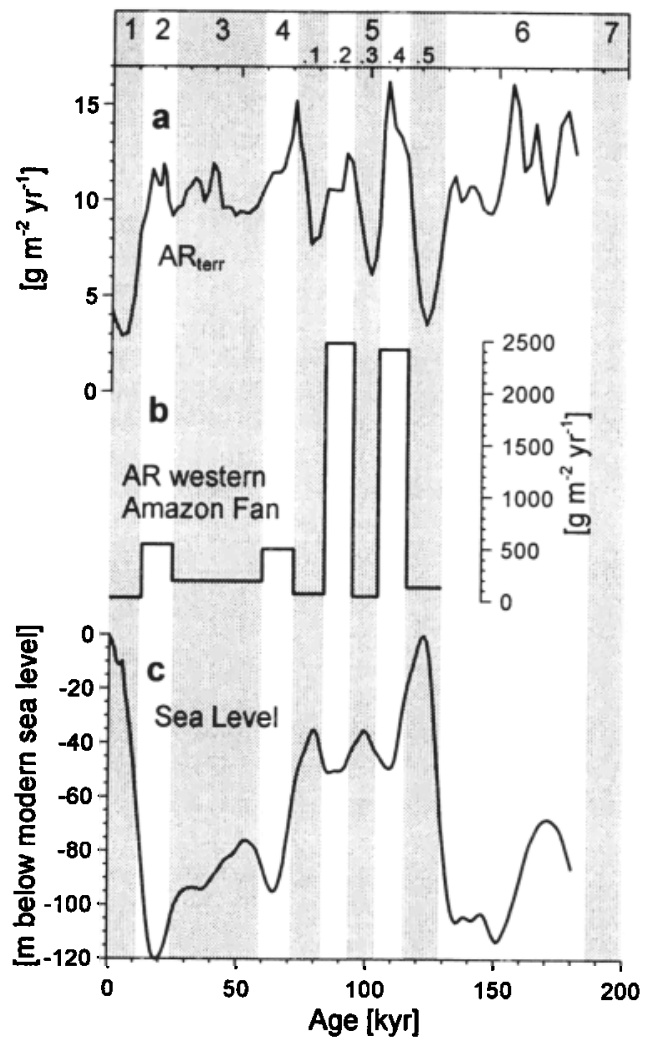

Figure 10. Comparison of (a) ${ }^{230} \mathrm{Th}$-normalized accumulation rates of terrigenous sediment for core GeoB 1523-1, (b) accumulation rates on the western Amazon Fan deduced from Ocean Drilling Program core site 942 [Schlünz et al., 1999], and (c) SPECMAP standard $\delta^{18} \mathrm{O}$ stack as an indicator of sea level 


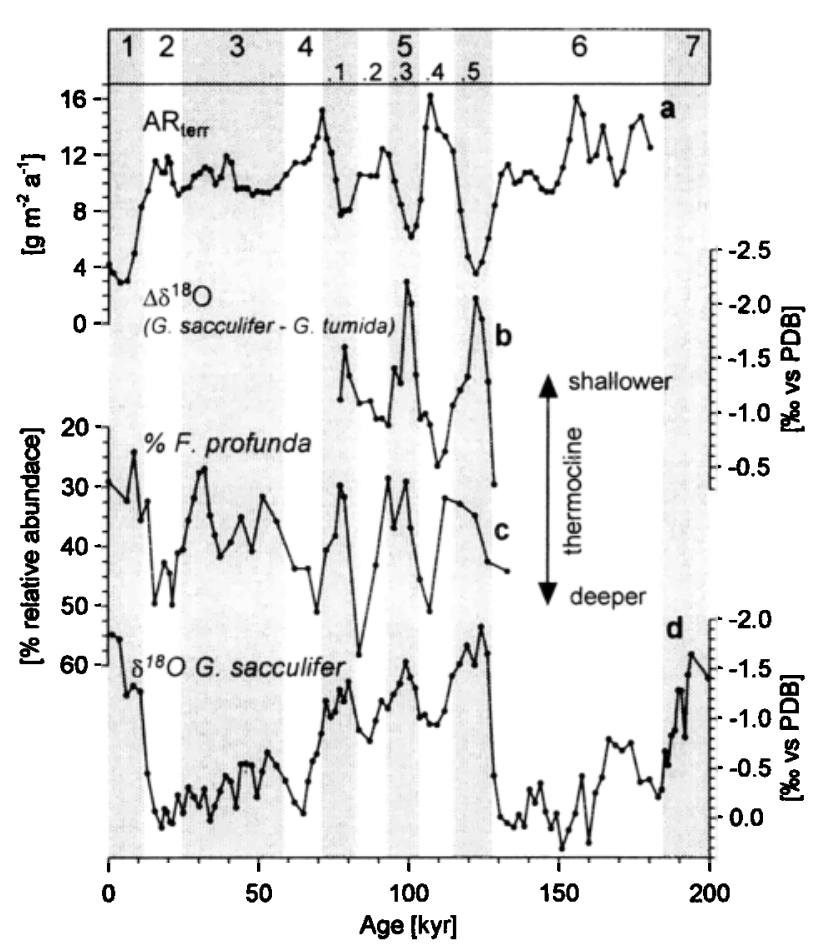

Figure 11. Comparison of (a) ${ }^{230} \mathrm{Th}$-normalızed accumulation rates of terrigenous sediment, (b) $\delta^{38} \mathrm{O}$ difference between $G$ sacculifer and $G$. tumida, (c) relative abundances of Florisphaera profunda (data are from Kinkel et al [2000]) as indicators of thermocline depth, and (d) $\delta^{18} \mathrm{O}$ of G. sacculffer.

diminished or the NBC retroflection was intensified. Because today the transport volume of the NBC and the seasonal occurrence of the retroflection are associated with changes in mixed layer depth and thermocline (Figure 2), we suggest similar modifications for changes of the western equatorial surface circulation system on glacial-to-interglacial timescales. Intensification of eastward water mass transport as a result of strengthened SE trade winds should have caused a deepening of the thermocline and may have been coupled with enhanced transport of terrigenous particles from the Amazon mouth toward the Ceara Rise. If this presumption is true, then the thermocline should have been deep when accumulation rates of terrigenous sediment on top of the Ceará Rise were high.

To reconstruct late Quaternary variations in thermocline depth, we use the relative abundances of the calcareous coccolithophorid species $F$. profunda. [Kinkel et al., 2000] and the $\delta^{18} \mathrm{O}$ difference between the shallow-dwelling planktic foraminifera $G$. sacculifer and the deep-dwelling planktic foraminifera $G$. tumida (which only occurs during interglacials in the Atlantic Ocean, e.g., MIS 5). Besides changes in thermocline depth, $\Delta \delta^{18} \mathrm{O}$ variations may have also been influenced by variable Amazon freshwater supply to the Ceará Rise region. Hydrographic data [Levitus and Boyer, 1994], however, show that today, during boreal summer, low-salinity waters originating from the Amazon's freshwater plume are restricted to the upper $20 \mathrm{~m}$ (with salinity increasing from $33 \%$ at the surface to $35-36 \%$ at $20 \mathrm{~m}$ ), whereas $G$. sacculifer is assumed to record the conditions of the entire mixed layer [Duplessy et al., 1981; Fairbanks et al, 1982], (Figure 3).
We thus consider a possible $\Delta \delta^{18} \mathrm{O}$ deviation due to Amazonderived fresh water to be negligible.

The relative abundance of $F$. profunda is an indicator of past changes in nutricline depth [Molfino and McIntyre, 1990]. Since the depths of nutricline and thermocline vary almost concurrently, the percentage of $F$. profunda is likewise a proxy of thermocline depth. High abundances of $F$. profund $a$ are associated with a deep nutricline (thermocline), and low abundances are associated with a shallow nutricline (thermocline). During MIS 5, changes in thermocline depth reconstructed from $\Delta \delta^{18} \mathrm{O}$ (Figure $1 \mathrm{lb}$ ) very closely reflect variations in the accumulation rate of terrigenous sediment on top of the Ceará Rise (Figure 11a). Low $\Delta \delta^{18} \mathrm{O}$ values (deep thermocline) are associated with high accumulation rates during oxygen isotope substages 5.4 and 5.2, whereas high $\Delta \delta^{18} \mathrm{O}$ correlates with low accumulation rates during substages $5.5,5.3$, and 5.1. Relative abundances of $F$ profunda show a pattern similar to the $\Delta \delta^{18} \mathrm{O}$ record with high abundances (shallow thermocline) during periods of low accumulation rates of terrigenous sediment and vice versa. Together, variations in $\Delta \delta^{18} \mathrm{O}$ and $F$ profunda percentages suggest that the thermocline in the western tropical Atlantic was deep (shallow) when the supply of Amazon-derived siliciclastics to the Ceará Rise was high (low).

\subsection{Implications for Late Quaternary Surface Water Circulation}

Because surface ocean circulation is largely wind-driven, it is reasonable to search the motor for the late Quaternary thermocline variations in changes of the tropical atmospheric circulation system. Our data suggest that analogous to the modern situation in boreal summer (Figure 2), precessionalforced intensification of the SE trades piled up water in the western equatorial Atlantic 1-2 kyr before ice volume maxima/sea level minima. We propose that the resultant W-E pressure gradient was associated with a strengthening or prolongation of the annual duration of the NBC retroflection and a more vigorous eastward flow of the surface waters carrying Amazon-derived suspensates toward the Ceará Rise. This scenario is supported by late Quaternary fluctuations in $\mathrm{Al} / \mathrm{Ti}$ ratios determined by Zabel et al [1999] along core GeoB 1523-1 and another sediment core recovered from the Mid-Atlantic Ridge at $2^{\circ} \mathrm{N}$ (GeoB 1505-2). Zabel et al. [1999] presented evidence that the terrigenous mineral fraction of the two sediment cores mainly originates from the Amazon's particulate load and suggested the eastward flowing NECC as the most likely carrier for Amazon-derived siliciclastics toward the Ceará Rise and farther east. $\mathrm{Al} / \mathrm{Ti}$ fluctuations of core GeoB 1523-1 are probably related to variations in grain size, which in turn, appear to be controlled by changes in NBC and NECC current velocity [Zabel et al, 1999]. The $\mathrm{Al} / \mathrm{Ti}$ record exhibits a strong precessional component that is in phase with the $A_{\text {terr }}$ fluctuations determined in this study (Figure 7a). This in-phase relationship further corroborates our assumption of orbitally forced changes in the intensity of the NBC retroflection driven by SE trade wind changes. A possible strengthening of the NBC retroflection and concurrent decrease of westward transport of warm upper layer water agree with recent observations on a 
weakening of the Gulf Stream during the LGM. LynchStieglitz et al. [1999] have shown that the Gulf Stream, as part of the same circulation system transporting heat from the tropics to the northern North Atlantic, was reduced during the LGM by one third of the modern value. Taken together it seems that cold climates coincide with a reduced flow of warm water to the high latitudes of the North Atlantic.

\section{Conclusions}

Small-scale changes in the illite/smectite ratio of a sediment core from the Ceará Rise, spanning the past $380 \mathrm{kyr}$, imply that Amazonian climate was dominated by a $100 \mathrm{kyr}$ cyclicity with drier conditions during glacials. The deposition of ${ }^{230} \mathrm{Th}_{\mathrm{ex}}$ on top of the Ceará Rise matches its local production in the overlying water column and provides evidence that terrigenous sediment particles predominantly reached the studied site within the upper water layers. On glacial-interglacial timescales the terrigenous sediment supply to the top of the Ceara Rise varied with a strong $23 \mathrm{kyr}$ periodicity and depended on both the distance of the Amazon River mouth to the shelf edge, controlled by sea level changes and shelf topography, and the flow direction of the Amazon freshwater plume, modified by changes in the equatorial surface current system. During cold climatic stages, trade wind intensity and SEC current velocity were probably stronger because of an increased thermal gradient between the high and low latitudes, resulting in a pileup of waters in the western tropical Atlantic. We suggest that the NBC retroflection was intensified causing a stronger deflection of the Amazon's freshwater plume and a more short-distance terrigenous sediment supply to the Ceará Rise.

Acknowledgments. We thank Monika Segl and Birgit MeyerSchack for oxygen isotope measurements and Silvia Janisch for her help with the sample preparation for clay mineral analysis. K. Billups and an anonymous reviewer made important suggestions which improved the manuscript. This study was supported by the Deutsche Forschungsgemeinschaft (Sonderforschungsbereich 261 at Bremen University, contribution 302). Data are available from the PANGAEA database (www.pangaea.de/Projects/GeoB/CRuehlemann).

\section{References}

Aston, S R., R Chester, L R Johnson, and R C Padgham, Eolian dust from the lower atmosphere of the eastern Atlantic and Indian Oceans, China Sea and Sea of Japan, Mar Geol , 14, 15-28, 1973

Bacon, $M P$, Glacial to interglacial changes in carbonate and clay sedimentation in the Atlantic Ocean estımated from Th-230 measurements, Isol Geoscl, 2, 97-111, 1984

Barreto, L A, J D Milıman, C A B Amaral, and O Francisconı, Northern Brazıl, in Upper. Continental Margin Sedimentation Off Brazıl, Contrib to Sedimentol, vol 4, edited by J D. Millinan and C P Summerhayes, pp |]-43, Schwelzerbart, Stuttgar, Germany, 1975

Billups, K, A C Ravelo, J C Zachos, and R D Norrıs, Link between oceanıc heat transport thermohaline circulation, and the Intertropical Convergence Zone in the early Pliocene Atlantic, Geology, 27, 319-322, 1999

Chamley, H, Clay Sedimentology, 623 pp, Sprunger-Verlag, New York, 1989

Chester, R, H Elderfield, J J Griftin, L R Johnson, and R C Padgham, Eolıan dust along the eastern margins of the Atlantic Ocean, Mar Geol, 13,91-105, 1972

Cochrane, J D, Low sea-surface salımity off northeastern South America in summer 1964 $J$ Mar Res, 27, 327-334, 1969

Damuth, J E, Late Quaternary sedimentation in the western equatorial Atlantic, Geol Soc Am $B u l l, 88,695-710,1977$

Damuth, J E, and R W Fairbridge, Equatorıal Atlantic deep-sea arcosic sands and ice-age aridity in tropical South America, Geol Soc Am Bull, 81, 189-206, 1970

Debrabant, P, M Lopez, and H Chamley, Clay inineral distribution and significance in Quaternary sediments of the Amazon Fan, Proc Ocean Drill Program Sci Results, 155, 177-192, 1997

Delany, A C, D W Parkın, J J Griflin, E D Goldberg, and B E F Reimann, Aırborne dust collected at Barbados, Geochm Cosmochm Acta, 31, 885-909, 1967

Dessier, A, and J R Donguy, The sea surface salinity in the tropıcal Atlantıc between $10^{\circ} \mathrm{S}$ and $30^{\circ} \mathrm{N}$-seasonal and interannual variations (1977-1989), Deep Sea Res , 4I, 81-100, 1994

Duplessy, J-C, P L Blanc, and A W H Bé, Oxygen-18 enrıchment of planktonıc foramına- fera due to gametogenic calcification below the euphotic zone, Science, 2J3, 1247-1250, 1981

Faırbanks, R G, M Sverdlove, R Free, P H Wiebe, and A W H Bé, Vertical distribution and isotopic fractionation of living planktonic foraminifera from the Panama Basin, Nature, $298,841-844,1982$

Francoss, $R$, and $M P$ Bacon, Vartations in terrigenous input into the deep equatoria Atlantıc durıng the past 24,000 years, Scrence, 25I, 1473-1476, 1991

Francoss, R, M P Bacon, and D O Suman Thorium 230 profilıng in deep-sea sedıments High-resolution records of tlux and dissolution of carbonate in the equatorial Atlantıc during the last 24,000 years, Paleoceanography, 5 $761-787,1990$

Frank, M, R Gersonde, and A Mangını Sediment redistribution, ${ }^{210} \mathrm{Th}_{\mathrm{e}}$-norinalization and implications for the reconstruction of particle flux and export paleoproductivity, in Use of Proxies in Paleoceanography Examples from the South Atlanic, edited by G Fischer, and G Wefer, pp 409-426, SpringerVerlag, New York, 1999

Gibbs, R J, The geochemistry of the Amazon River system, Part I, The factors that control the salinity and the coinposition and concentration of the suspended solids, Geol Soc Am. Bull, 78, 1203-1232, 1967

Gingele, F X, F Schmieder, T von Dobeneck, $R$ Petschıck, and C Ruhlemann, Terrıgenous flux in the Rio Grande Rise area during the past $1500 \mathrm{ka}$ Evidence of deepwater advection or rapid response to contunental rainfall patterns? Paleoceanography, 14, 84-95, 1999

Haberle, S G, and M A Maslın, Late Quaternary vegetation and climate change in the Amazon Basın on a 50,000 year pollen record from the Amazon Fan, ODP Site 932, Quat Res, 51, 27-38, 1999

Harris, S E and A C Mix Pleistocene precipitation balance in the Amazon Basın recorded in deep sea sediments, Quat Res., 5I, 14-26, 1999

Harris, S E, A C Mix, and T King, Biogenıc and terrigenous sedimentation at Ceara Rise, western tropical Atlantic, supports PlocenePleıstocene deepwater linkage between hemıspheres, in Proc Ocean Drill Program, ScI Results, 154, 331-345, 1997

Hastenrath, S, C/mmate Dynamics of the Tropics, Kluwer Acad, Norwell, Mass , 1996
Hastenrath, S, and J Merle, Annual cycle of subsurface thermal structure in the Tropical Atlantıc Ocean, $J$ Phys Oceanogr , 17, 15181538,1987

Imbrie, J, J D Hays, D G Martınson, A McIntyre, J J Morley, N G Pisias, W L Prell, and N J Shackleton, The orbital theory of Pleistocene climate Support from a revised chronology of the marıne $\delta^{18} \mathrm{O}$ record, in Milankovitch and Climate, Part I, edited by A Berger et al, pp 269-305, D Reıdel, Norwell, Mass , 1984

Imbrie, J, A Mclintyre, and A Mix, Oceanıc response to orbital forcing in the late Quaternary Observational and experimental strategies, in Climate and Geo-Science, edited by A Berger, S Schneider, and J. -C. Duplessy, pp 121-164, Kluewer Academıc Publishers, Dordrecht, 1989

Kineke, G C, R W Sternberg, J H. Trowbridge, and $W, R$ Geyer, Fluid-mud processes on the Amazon contunental shelf, Cont. Shelf Res, 16 $667-696,1996$

Kınkel, $\mathrm{H}, \mathrm{K} \cdot \mathrm{H}$ Baumann, and $\mathrm{M}$ Cepek, Coccolithophores in the equatorial Atlantic Ocean Response to seasonal and Late Quaternary surface water varıability, Mar: Micropaleontol , 39, 87-112, 2000

KuehI, S A, D J DeMaster, and C. A Nittrouer Nature of sediment accumulation on the Amazon continental shelf, Cont Shelf Res., 6 , 209-225, 1986

Lentz, S J, Seasonal varıations in the horizontal structure of the Amazon Plume inferred from historical hydrographic data, $J$ Geophys Res, $100,2391-2400,1995$

Levitus, S, and T P Boyer, World Ocean Atlas 1994, volume 4, Temperature, NOAA Atlas NESDIS 4, 117 pp, Natl Oceanic and Atmos Admin, Silver Spring, Md , 1994

Lynch-Stieglitz, J, W B Curry, and N Slowey, Weaker Gulf Stream in the Florida Straits during the Last Glacial Maximum, Nature, 402, 644-648, 1999

Maslın, M, S Burns, $H$ Erlenkeuser, and C Hohnemann, Stable isotope records from sites 932 and 933, Proc Ocean Drill Program Scl Results, I55, 305-318, 1997

Milliman, J D, and R $H$ Meade, World-wide delivery of river sediment to the oceans, $J$ Geol, 9I, 1-2], 1983

Millıman, J D , C P Summerhays, and $\mathrm{H}$ T Barretto, Quaternary sedımentation on the 
Amazon continental margın A model, Geol Soc Am Bull, 86, 610-614, 1975

Mıx, A C, J Le, and N J Shackleton, Benthıc foramınıferal stable isotope stratigraphy of Site 846 0-1 8 MA, Proc Ocean Drill. Program, Scl Results, 138, 839-847, 1995

Molfino, B, and A McIntyre, Precessional forcing of nutricline dynamics in the Equatorial Atlantic, Science, 29, 766-769, 1990

Mulitza, S, A Durkoop, W Hale, G Wefer, and H -S Niebler, Planktonıc foramınıfera as recorders of past surface-water stratitication, Geology, 25, 335-338, 1997

Muller-Karger, F E, C R McClain, and P L Richardson, The dispersal of the Amazon's water, Nature, 333, 56-59, 1988

Nittrouer, C A, and D J DeMaster, The Amazon shelf settıng Tropical, energetic, and influenced by a large river, Cont Shelf Res 16, 553-573, 1996

Nittrouer, C A, T B Curtın, and D J DeMaster, Concentration and flux of suspended sedımen on the Amazon contunental shelf, Cont Shelf Res, 6, 151-174 1986

Paul, A, S Mulitza, J Patzold, and T Wolff Siınulation of oxygen isotopes in a global ocean model, in Use of Proxies in Paleoceanography, edited by G Fischer and $G$ Wefer, pp 655-686, Sprınger-Verlag, New York, 1999

Petschık, R, G Kuhn, and F X. Gingele, Clay mineral distribution in surface sediments of the South Atlantic Sources, transport, and relation to oceanography, Mar Geol, I30, 203-229. 1996

Phılander, S G $\mathrm{H}$, and $\mathrm{R} \mathrm{C}$, Pacanowski, The mass and heat budget in a model of the tropical Atlantic Ocean, $J$ Geophys Res, 9I, 14,212 $14,220,1986 \mathrm{~b}$

Picaut, J, P Servaın, M LeComte, $M$ Seva, $S$ Lukas, and G Rougier, FOCAL clımatıc atlas of the tropical Atlantic, wind stress and sea surface temperature 1964-1979, 465 pp, Univ Bretagne Occidentale, Brest, France, 1985

Ravelo, A C, and R G Farrbanks, Oxygen Isotopic composition of multiple species of planktonıc foramınifera Recorders of the modern photic zone temperature gradient, Paleoceanography, 7, 815-831, 1992

Richardson, $P$ L, and $T$ K McKee, Average seasonal variation of the Atlantic equatorial currents from historical ship drifts, J. Phys. Oceanogr., 14, 1226-1238, 1984

Rıchardson, P L, and G Reverdın, Seasonal cycle of velocity in the Atlantic North Equatorial Countercurrent as measured by surface drifters, current meters, and shıp drıft, $J$ Geophys Res, 92,3691-3708, 1987

Ruhlemann, C, M Frank, W Hale, A Mangını, S Mulitza, P J Muller, and G Wefer, Late Quaternary productivity changes in the western equatorial Atlantic Evidence from ${ }^{230} \mathrm{Th}-$ normalized carbonate and organic carbon accumulation, Mar Geol, /35, 127-152, 1996

Schlunz, B, R R Schneıder, P J Muller, W J Showers, and $G$ Wefer, Terrestrial organic carbon accumulation on the Ainazon Deep Sea Fan durmg the last glacial sea level low stand Chem Geol, 159, 263-281, 1999

Schneider, R, P J Muller, B Schlunz, M Segl, W J Showers, and G Wefer, Upper Quaternary western Atlantıc paleoceanography and terrigenous sedimentation on the Amazon fan A view from stable isotopes of planktonıc foraminıfers and bulk organıc matter, in Proc Ocean DrIll Program ScI Results, 155, 319. 333,1997

Schott, F, L Stramma, and J Fischer, The warm water inflow into the western tropical Atlantıc boundary regıme, spring 1994, J. Geophys. Res, $100,24,745-24,760,1995$

Schulz, H. D et al, Berıcht und erste Ergebnisse uber die METEOR-Fahrt M 16/2, RecifeBelem, 284 - 2I.5 199I, Fachbereich Geowissenschaften, Universitat Bremen, Bremen, Germany, 1991

Schulz, $M$, and K Stattegger, SPECTRUM Spectral analysis of unevenly spaced paleoclımatic tıme series, Comput. \& Geoscı, 23, 929-945, 1997

Schweıtzer, $P \mathrm{~N}$, and $\mathrm{G} P$ Lohınan, Ontogeny and habitat of modern menardıform planktonic foraminifera, $J$ Foranimiferal Res, 21 , 332-346, 1991

Shackleton, N, Attainment of isotopic equilibrium between ocean water and the benthonsc foraminifera genus Uvigerina Isotopic changes in the ocean during the last glacial, Collog Int. CNRS , 2/9, 203-209, 1974

Stute, M , M Forster, H Frischkorn, A Serejo, J F Clark, P Schlosser, W S Broecker, and G Bonanı, Coolıng of Tropical Brazil $\left(5^{\circ} \mathrm{C}\right)$ during the Last Glacial Maximum, Science, $269,379-383,1995$

Tiedemanu, $R$, and $S \quad O$ Franz, Deep-wate circulation, chemistry, and terrigenous sediment supply in the equatorial Atlantic durıng the Pliocene, 33.2 $6 \mathrm{Ma}$ and 5-4 $5 \mathrm{Ma}$ Proc Ocean Drill Program Sol Results, 154, 299. 318,1997

Van der Hammen, T, and M L Absy, Amazonia during the last glacial, Palaeogeogr, Palaeoclimatol, Palaeoecol, 109, 247-261, 1994

Verardo, D J, and A McIntyre, Production and destruction Control of biogenous sedimentation in the tropical Atlantic $0-300,000$ years B P , Paleoceanography, 9, 63-86, 1994

Welch, P D . The use of tast Fourier transform for the estımation of power spectra A method based on averaging over short, modified perıodograms, IEEE Trans. Audio Electroacoust., 15, 70-73, 1967

Willams, D F, A W H Be, and R G Fairbanks, Seasonal stable isotopic variations in living planktonıc foramınıfera from Bermuda plankton tows, Palaeogeogr, Palaeoclimatol. Palaeoecol , 33, 71-102, 1981

Zabel, M , T Bıckert, L Dittert, and R R Haese, The significance of the sedimentary $A I T_{1}$ ratio as an indicator for variations in the circulation patterns of the equatorial North Atlantic Paleoceanography, /4, 789-799, 1999

B Diekmann, Alfred-Wegener-Instıtut fur Polar und Meerseforschung, Postfach 120161 , D27515 Bremerhaven, Germany (bdiekmann@awıbremerhaven de)

M Frank, Institute for Isotope Geology and Mıneral Resources, Department of Earth Sciences, ETH Zentrum, NO C6I, Sonneggstrasse 5, CH8092 Zurıch, Switzerland (frank@erdw ethz ch)

Stefan Mulıtza and Carsten Ruhlemann, Unıversitat Bremen, FB Geowissenschaften, Postfach 3304 40, D-28334 Bremen, Germany, (smul@ palmod uni-bremen de, ruehl@unı-bremen de)

(Recelved October 26, 1999, revised December 14,2000 accepted January 26,2001 ) 